made, the more it will be influenced by organic binding. This means that a fall in the 20-minute uptake during treatment with carbimazole is due partly to impairment of organic binding, and this effect must be taken into account if conclusions on thyroid suppression are based on this measurement. Of interest in this context are some recent observations by Shimmins et al. (1971), who found that the 20-minute uptake of ${ }^{132}$ I fell by about $20 \%$ as soon as treatment with carbimazole was started.

Attempts to predict the outcome of antithyroid drug treatment on the basis of thyroid suppressibility have met with limited success (Alexander et al., 1970; Goolden et al., 1971; Lowry et al., 1971). Suppression is not necessarily indicative of long-term remission, and patients who fail to suppress do not always relapse when treatment is discontinued. Despite these limitations the examination of thyroid function during treatment may sometimes be helpful, and for this purpose ${ }^{90} \mathrm{Tc}^{\mathrm{m}}$ uptake would seem to be the most appropriate method.

In our experience ${ }^{99} \mathrm{Tc}^{\mathrm{m}}$ uptake measurements have proved very satisfactory for the routine assessment of thyroid function. In the absence of a direct comparison it cannot be said that they are any more efficient than early radioiodine uptake tests in differentiating between euthyroid and hyperthyroid individuals, but we think it unlikely that such a comparison would show any great difference. Points in favour of ${ }^{99} \mathrm{Tc}^{\mathrm{m}}$ are that it gives a small radiation dose to the thyroid and that tests can be repeated at short time intervals. Furthermore, techniques for measuring the uptake of this radioisotope allow accurate correction for extrathyroidal activity, an essential requirement for any early thyroid uptake measurement. The reproducibility of the method described is such that suppression tests can be used when necessary even when thyroid uptake is within the normal range. Finally, ${ }^{90} \mathrm{Tc}^{\mathrm{m}}$ is particularly well suited for the assessment of thyroid function in patients being treated with an antithyroid drug.

This work was supported in part by a grant from the Medical Research Council.

\section{References}

Alexander, W. D., Harden, R. McG., and Shimmins, J. (1966). Lancet, 2, 1041 .

Alexander, W. D., Harden, R. McG., Shimmins, J., McLarty, D., and McGill, P. (1967). Fournal of Clinical Endocrinology, 27, 1682.

Alexander, W. D., et al. (1970). Fournal of Clinical Endocrinology, 30, 540.

Andros, G., Harper, P. V., Lathrop, K. A., and McCardle, R. J. (1965). fournal of Clinical Endocrinology, 25, 1067.

Atkins, H. L., and Richards, P. (1968). Fournal of Nuclear Medicine, 9, 7 Berson, S. A., and Yalow, R. S. (1955). Fournal of Clinical Investigation, 34, 186.

de Garreta, A. C., Glass, H. I., and Goolden, A. W. G. (1968). British fournal of Radiology, 41, 896 .

Goolden, A. W. G., Glass, H. I., and Silvester, D. J. (1968). British Fournal of Radiology, 41, 20.

Goolden, A. W. G., Brown, M., and Williams, E. D. (1971). In Further Advances in Thyroid Research, ed. K. Fellinger and R. Höfer. Vienna, Wiener Medizinischen Akademie.

Ibbertson, H. K., Hunton, R. B., White, B. Mcl., and Gluckman, P. D. (1971). In Further Advances in Thyroid Research, ed. K. Fellinger and R. Höfer. Vienna, Wiener Medizinischen Akademie.

Koutras, D. A., and Sfontouris, J. (1966). Fournal of Endocrinology, 35, 135 Lowry, R. C., Lowe, D., Hadden, D. R., Montgomery, D. A. D., and Weaver, J. A. (1971). British Medical fournal, 2, 19

Shimmins, J., Hilditch, T., Harden, R. McG., and Alexander, W. D. (1968). Fournal of Clinical Endocrinology, 28, 575.

Shimmins, J., Alexander, W. D., McLarty, D. G., Robertson, J. W. K., and Sloane, D. J. P. (1971). Fournal of Nuclear Medicine, 12, 51 .

Thomas, I. D., Oddie, T. H., and Myhill, J. (1960). Fournal of Clinical Endocrinology, 20, 1601 .

Williams, E. D., Glass, H. I., Goolden, A. W. G., and Satyavanich, S. (1971). Fournal of Nuclear Medicine. In Press.

\title{
Pyrantel Embonate in Treatment of Hookworm Infestation
}

\author{
ot al \\ K. N. PANDEY, ${ }^{2}$ S. G. SHARATHCHANDRA, G. S. SARIN, N. K. AJMANI, H. K. CHUTTANI
}

British Medical fournal, 1971, 4, 399-400

\section{Summary}

The efficacy of pyrantel embonate (1,4,5,6-tetrahydro-1methyl-2-(trans-2-(2-thienyl)-vinyl)-pyrimidine embonic acid salt; Combantrin) was evaluated in 60 cases of hookworm infestation. They were divided into six groups of 10 cases. Pyrantel embonate was administered orally, in dosage schedules (randomized) of $100,75,50,20,15$, and $10 \mathrm{mg} / \mathrm{kg}$ of body weight. The stool examination for hookworm ova and coproculture were positive in each case. The predominant species was Ancylostoma duodenale (in 58 patients). After treatment with pyrantel embonate the stool examination for hookworm ova and coproculture were negative on the 10th and 15th days in each group. The blood levels of the drug were significantly higher in patients receiving 100 and $75 \mathrm{mg} / \mathrm{kg}$ body weight. In groups $A$ and $B$ one patient experienced nausea and vomiting on the day of administration of drug. There were no abnormal changes in liver function

Maulana Azad Medical College, New Delhi 1, India K. N. PANDEY, M.B., B.S., Senior Resident in Medicine S. G. SHARATHCHANDRA, M.D., Registrar in Medicine G. S. SARIN, B.SC., Assistant Research Officer

N. K. AJMANI, M.D., Lecturer in Medicine

H. K. CHUTTANI, M.D., Professor of Medicine tests or blood urea levels in any of the groups. Hence the optimum single dose of the drug effective against hookworm infestation is $10 \mathrm{mg} / \mathrm{kg}$ body weight, and further studies are required to evaluate the minimum effective dose of pyrantel embonate.

\section{Introduction}

Pyrantel embonate (Pamoate, Combantrin) is a 1,4,5,6tetrahydro-1-methyl-2-(trans-2-(2-thienyl)-vinyl)-pyrimidine embonic acid salt. It is a yellow crystalline solid, with a molecular weight of 594.7. It has the molecular formula $\mathrm{C}_{34} \mathrm{H}_{30} \mathrm{O}_{6} \mathrm{~N}_{2}$ and the structural formula shown in the Diagram. It has been shown<smiles>CN1CCCNC1=Cc1cccs1</smiles><smiles>O=C(O)c1cc2ccccc2c(Cc2c(O)c(C(=O)O)cc3ccccc23)c1O</smiles>

to be very effective against pinworm, roundworm, and hookworm of animals (Austin et al., 1966;. Cornwell and Hones, 1968; Howes and Lynch, 1967). The present study was under- 
taken to determine its efficacy in eradicating the hookworm infestation, and to evaluate its optimum dosage and safety in human beings.

\section{Patients and Methods}

The study was carried out in the departments of gastroenterology and medicine of Maulana Azad Medical College, New Delhi, from early 1969 to early 1970. Sixty patients (45 males and 15 females) with a positive stool for hookworm ova were submitted to this study. Their ages ranged from 16 to 70 years and their mean body weight was $42.67 \pm 7.17 \mathrm{~kg}$, with a range of 25 to $55 \mathrm{~kg}$. Detailed clinical features were recorded.

Routine haematological studies and liver function testsnamely, serum bilirubin, alkaline phosphatase, serum aspartate aminotransferase, serum alanine aminotransferase, and blood urea estimation-were undertaken before treatment and on the third and tenth days after treatment, standard methods being used (Varley, 1967).

Twenty-four-hour sample of stool was examined for faecal egg load by the Stoll and Hausheer (1926) technique on three consecutive days before therapy and on the 10th, 11th, 12th, 18 th, 19th, and 20th days after administration of the drug. No patients with an ova count below $3,000 / \mathrm{g}$ of faeces was included in this trial. The 24-hour sample of stool was sieved for identification of adult worms on the 1st, 2 nd, and 3rd days of treatment. Coproculture was performed according to the method of Belding (1965) before treatment and on the 10th, 15th, and 20th days after treatment.

Dosage Schedule.-Six dosage schedules were used: group A, $100 \mathrm{mg} / \mathrm{kg}$ body weight, group $B, 75 \mathrm{mg} / \mathrm{kg}$, group C, $50 \mathrm{mg} / \mathrm{kg}$, group $D, 20 \mathrm{mg} / \mathrm{kg}$, group E, $15 \mathrm{mg} / \mathrm{kg}$, and group $\mathrm{F}, 10 \mathrm{mg} / \mathrm{kg}$. The drug was supplied in tablet form of $50-, 125-$, and $250-\mathrm{mg}$ strength. It was administered orally in a single dose, on an empty stomach, and food was withheld for two hours. The allocation was randomized on the basis of a preplanned schedule. There were 10 patients in each group. The blood level of pyrantel embonate was estimated at 4 and 12 hours after administration of the drug. Patients were kept in the ward for over 20 days and a careful daily record of any symptoms developing during this period was noted. The blood level of pyrantel embonate was estimated colorimetrically (method provided by the Research Laboratories of Pfizer Limited).

\section{Observations and Comments}

The results of therapy are summarized in Table $I$. The coproculture was positive in all cases before treatment, and identification of species showed Ancylostoma duodenale in 57 patients and Necator americanus in two. Species identification after deworming by examination of adult worms in stool gave similar results, and there was a direct correlation between hookworm ova count and worms expelled. The stool was free from ova on the 10th, 12th, 15th, 18th, 19th, and 20th days. The coproculture was negative on the 10th, 15th, and 20th days in all six groups (Table I). Hookworm ova were not found by the concentration method between the 10th and 20th posttreatment days. Hence complete eradication $(100 \%)$ of hookworm ova was achieved in each group.

There was no evidence of hepatocellular or renal toxicity as indicated by serum bilirubin, alkaline phosphatase, transaminase
TABLE I-Summary of Results of Drug Therapy in Different Groups

\begin{tabular}{|c|c|c|c|c|c|}
\hline Grou p & $\underset{\substack{\text { Mean } \\
\text { (mg) }}}{\stackrel{\text { Mosage }}{(m g)}}$ & $\begin{array}{c}\text { Pretreatment } \\
\text { Hookworm } \\
\text { Ova Load } \\
\text { (Mean of } \\
3 \text { days) (eggs } \\
\text { per } \mathrm{g} \text { of faeces) }\end{array}$ & $\begin{array}{c}\text { Copro- } \\
\text { culture } \\
\text { before } \\
\text { Treatment }\end{array}$ & $\begin{array}{c}\text { Posttreatment } \\
\text { Hookworm Ova } \\
\text { Count on } \\
\text { Day } 10,11,12 \text {, } \\
18,19 \text { and } 20\end{array}$ & $\begin{array}{c}\text { Copro- } \\
\text { culture } \\
\text { after } \\
\text { Treatment } \\
\text { on Day 10, } \\
\text { 15, and } 20\end{array}$ \\
\hline $\begin{array}{l}\mathbf{A} \\
\mathbf{B} \\
\mathbf{C} \\
\mathbf{D} \\
\mathbf{E} \\
\mathbf{F}\end{array}$ & $\begin{array}{r}4,180 \pm 666 \cdot 0 \\
3,345 \pm 428 \cdot 4 \\
2,005 \pm 439.5 \\
780 \pm 152.9 \\
660 \pm \frac{105 \cdot 2}{ \pm} 430 \pm 55.7\end{array}$ & $\begin{array}{l}6,166 \pm 2,831 \\
4,389 \pm 1,584 \\
4,436 \pm 1,843 \\
5,119 \pm 1,547 \\
4,859 \pm 1,375 \\
5,726 \pm 3,391\end{array}$ & $\begin{array}{l}\text { Positive } \\
\text { Postiive } \\
\text { Positive } \\
\text { Positive } \\
\text { Positive } \\
\text { Positive }\end{array}$ & $\begin{array}{l}\mathrm{Nil} \\
\mathrm{Nil} \\
\mathrm{Ni} \\
\mathrm{Nil} \\
\mathrm{Nil} \\
\mathrm{Nil}\end{array}$ & $\begin{array}{l}\text { Negative } \\
\text { Negative } \\
\text { Negative } \\
\text { Negative } \\
\text { Negative } \\
\text { Negative }\end{array}$ \\
\hline
\end{tabular}

levels, and blood urea on the 3rd and 10th post-treatment days in any group. The differences in blood drug levels at 4 and 12 hours after administration of the drug were not significant in groups $C, D, E$, and F (Table II). In groups $A$ and $B$ the 12-hour blood level was significantly higher than at four hours (Table II). This shows a higher rate of absorption of the drug at 100 - and $75-\mathrm{mg} / \mathrm{kg}$ dosage. Though these dosage schedules seemed very effective, side effects like nausea and vomiting were noted in one patient each in groups A and B. Otherwise the drug was well tolerated.

TABLE II-Blood Levels of Pyrantel Embonate (P.E.) in Different Dosage Groups

\begin{tabular}{|c|c|c|c|c|c|c|c|}
\hline \multirow{2}{*}{ Group } & \multirow{2}{*}{$\begin{array}{l}\text { No. of } \\
\text { Cases }\end{array}$} & \multicolumn{2}{|c|}{ Blood Level of P.E. $(\mu \mathrm{g} / \mathrm{ml})$} & \multirow{2}{*}{$\begin{array}{c}\text { Mean } \\
\text { Diff. }\end{array}$} & \multirow{2}{*}{$\boldsymbol{\imath}$} & \multirow{2}{*}{ D.F. } & \multirow{2}{*}{$\mathbf{P}$} \\
\hline & & At 4 Hours & At 12 Hours & & & & \\
\hline $\begin{array}{l}\mathbf{A} \\
\mathbf{B} \\
\mathbf{C} \\
\mathbf{D} \\
\mathbf{E} \\
\mathbf{F}\end{array}$ & $\begin{array}{r}7 \\
6 \\
7 \\
10 \\
10 \\
10\end{array}$ & $\begin{array}{l}2.01 \pm 1.23 \\
1.87 \pm 1.25 \\
1.47 \pm 1.07 \\
0.80 \pm 0.26 \\
0.81 \pm 0.44 \\
0.75 \pm 0.28\end{array}$ & $\begin{array}{l}2.47 \pm 1.33 \\
2.33 \pm 1.47 \\
1.34 \pm 0.82 \\
0.86 \pm 0.40 \\
0.78 \pm 0.50 \\
0.61 \pm 0.41\end{array}$ & $\begin{array}{l}+0.46 \\
+0.46 \\
-0.13 \\
+0.06 \\
-0.03 \\
-0.04\end{array}$ & $\begin{array}{l}2.72 \\
4.70 \\
1.07 \\
0.62 \\
0.43 \\
0.49\end{array}$ & $\begin{array}{l}6 \\
5 \\
6 \\
9 \\
9 \\
9\end{array}$ & $\begin{array}{l}<0.05 \\
<0.01 \\
>0.05 \\
>0.05 \\
>0.05 \\
>0.05\end{array}$ \\
\hline
\end{tabular}

In this trial the drug was found to be effective in the eradication of hookworm infection even at the lowest dosage schedule of $10 \mathrm{mg} / \mathrm{kg}$. It is necessary to extend further trials of the drug at still lower dosage to find out the minimum effective dose against hookworm.

We are grateful to Dr. S. Padmavati, Director-Principal, Maulana Azad Medical College, New Delhi, for permission to publish this work. We are thankful to Dr. R. D. Mann, Medical Director of Pfizer Ltd., New York, and Dr. V. V. Apte, Medical Director of Pfizer Ltd., India, for providing the drug and a liberal grant for this study. We are also thankful to Mr. D. S. Ahluwalia, Deputy Director, Indian Standards Institution, New Delhi, for statistical analysis of the data.

Requests for reprints should be sent to Professor $\mathbf{H}$. K. Chuttani.

\section{References}

Austin, W. C., et al. (1966). Nature, 212 1273. Belding, D. L. (1965). Trext

Cornwel1, R. L., and Hones, R. M. (1968). Fournal of Tropical Medicine and Hygiene, 71, 165.

Howes, H. L., and Lynch, J. E. (1967). Youmal of Parasitology, 53, 1085. Stoll, N. R., and Hausheer, W. C. (1926). American fournal of Hygiene, 6, Suppl. p. 134 .

Varley, f. (1967). Practical Clinical Biochemistry, 4th edn. New York, Heinemann-Medical Books and Interscience Books. 